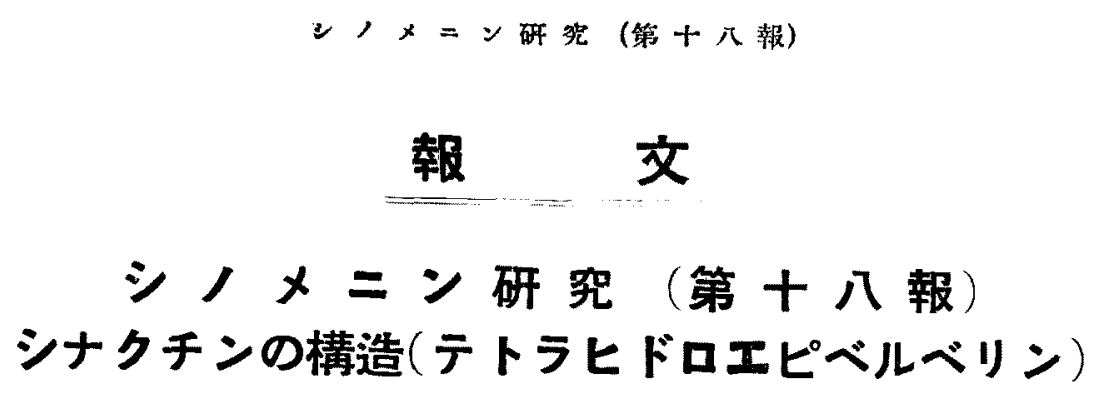

461

(昭和五年五月十三日受領 昭和五年七月甘五日印刷)

後藤格次鈴木英燿北里善次郎

シナクチン(Sinactin) は著者の一人後藤が初めてお性つづらふらら゙ (Sinomeniun Acutum Rehder et Wilson) の根中より Sinomenin の副アルカロイドとして分蜼したるるのなり。當時後藤及び鈴 木等は該了ルカロイトK $\mathrm{C}_{19} \mathrm{H}_{21} \mathrm{O} \mathrm{O}_{4} \mathrm{~N}$ なる分子式を與へ且つ Tetrahydropapaverin 核を有する物なら んとの想像を發表せり。（但し同時に元素分析の結果 $\mathrm{C}_{20} \mathrm{H}_{93} \mathrm{O}_{4} \mathrm{~N}$ の可能なる事をる附記せり)。

著者等は此のアルカルイドに就き更に研究を進めたる結果茲に分子式を $\mathrm{C}_{20} \mathrm{H}_{21} \mathrm{O}_{4} \mathrm{~N}$ と改め且つ Sinactin は Tetrahydropapaverin 核老有するとあらすして Tetrahydroberberin 核を有するるのなる 事を決定せり。

Sinactin を酒精より再結する時柱無色細杜晶(融點 $175^{\circ} ;[\alpha]_{\mathrm{D}}^{100}=-312^{\circ}$ )となり $b^{3}$ )該監基は二箇の ヌトキシル基と一䇢のメチレンヂオキシ基とを有し且つ其醋酸溶液に浱硫酸を加ふれば初め無色な れどる漸次紫赤色を呈するに至る。Sinactin の吸收スペクトルは Tetrahydropapaverin 乃至 Tetrahydroberberin の其等と近似の吸收帶を有しこれにより兩者の互に酷似せる構造を有する事を推定 (得o $0^{4)}$

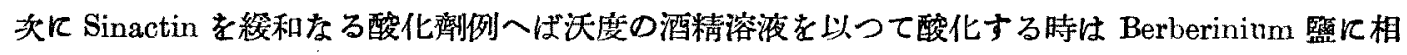
當する Sinactiniumchlorid, $\mathrm{C}_{20} \mathrm{H}_{18} \mathrm{O}_{4} \mathrm{NCl}$ の深黄色盛を生声。該物質㶎元により不活性 Sinactin と なり（瀜點 $168^{\circ} ）$ 其の凡ての性質は Perkin 及び Haworth 等”の合成せる Tetrahydroepiberberin (III)のそれ等とよく一致するを見る。

上述の結果よりして Sinactin は $l$ 形 Tetrahydroepiberberin 即ち一のメチレンヂオキシ基と二筒 のメトキシル基とが Tetrahydroberberin（I）のそれ等と相反的位置に存するアルカロイドる事を 推定し得。此處几於て著者等注 R. D. Haworth 数授の御厚意几依り邆附せられをる合成 Tetrahydroepiberberin と余等の不活性 Sinactin とを混融したるに毫る融點の降下を認めす作つて全く Sinactin 仕 $l$-Tetrahydroepiberberin Kして、(III)なる㩐造を有するアルカロイドる事を決定し得 tho

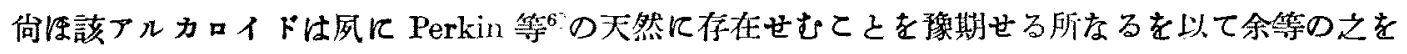
得える事は甚た興味することと信す。

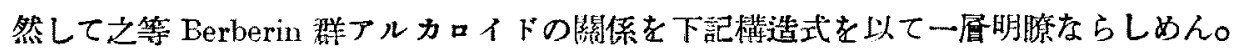

1) 本誌、50,560 (1929).

2) 同上、561.

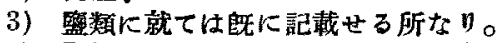

4) J. Dobbie and A. Lauder: J. Chem. Soc., 83, 614 (1903); Z. Kitasato: Acta Phytochimica, 3, 229 (1927).

5) W. H. Perkin, Jun.: J. Chem. Soc., 113, 512 (1916); R. D. Haworth and W. H. Perkin, Jun.: J. Chem. Soc., 129, 1777 (1926).

6) W. H. Perkin: J. Chem. Soc., 113, 494 (1918); Perkin a. R. D. Haworth: J. Chem. Soc., 131, 2261 (1927). 


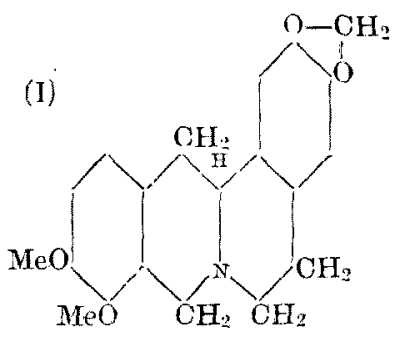

Tetrahydroberberin

(Ganadin)

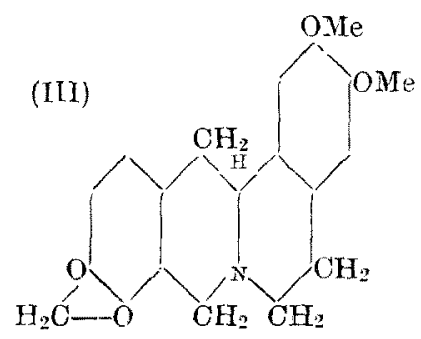

Tetrahydroepiberberin (Sinactin)

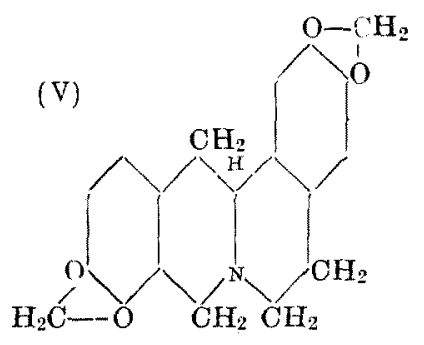

Tetrahydrocoptisin

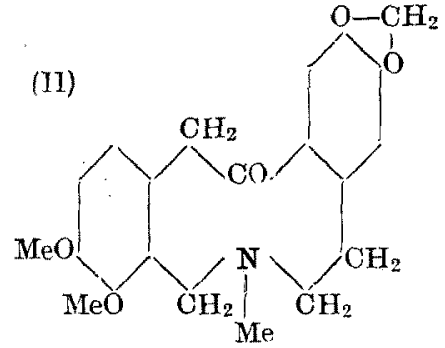

$\beta$-Homocbelidonin

(Allocryptopin)

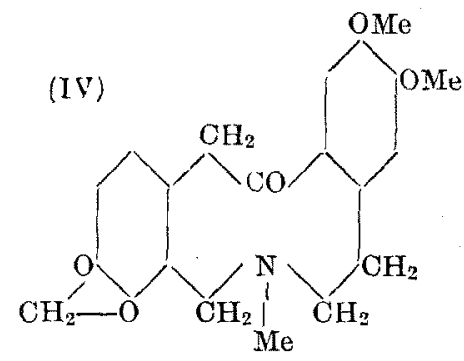

Cryptopin

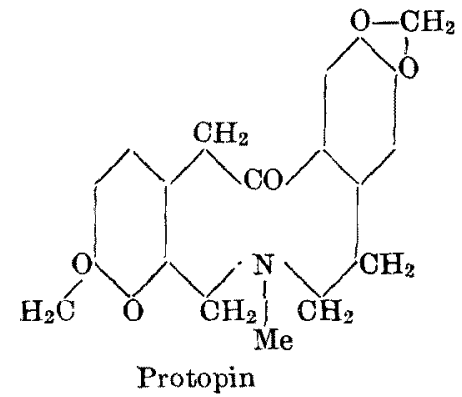

\section{宽驗の 部}

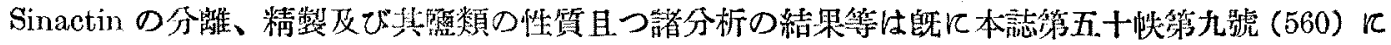
記载せらる。

Sinactin $の$ 元素分析

$3.467 \mathrm{mg}$. (物賀)， $9.021 \mathrm{mg} .\left(\mathrm{CO}_{2}\right), 2.002 \mathrm{mg} .\left(\mathrm{H}_{2} \mathrm{O}\right)$,

$5.552 \%("), 14.391 "("), 3.145 "(")$,

5.828 (") $, 15.183 "("), 3.289$ " ("),

$8.195 \%(\%), \quad 0.304 \mathrm{ccm} \quad \mathrm{N}_{2}\left(13.5^{\circ} 772 \mathrm{m.m}\right)$.

\begin{tabular}{|c|c|c|c|c|c|c|}
\hline $\mathrm{C}_{27} \mathrm{H}_{21} \mathrm{O}_{4} \mathrm{~N}(339)$ & 理論数 & $\mathrm{C}$ & 70.8 & $\mathrm{H}$ & 6.2 & $N$ \\
\hline & 筷聡数 & " & 70.9 & " & 6.4 & " \\
\hline & & " & 70.5 & $"$ & 6.3 & \\
\hline & & " & 710 & " & 6.3 & \\
\hline
\end{tabular}


不活性 Sinactin の裂法

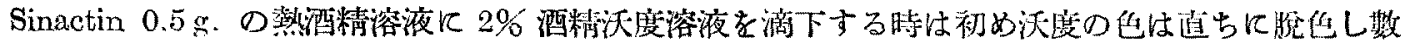

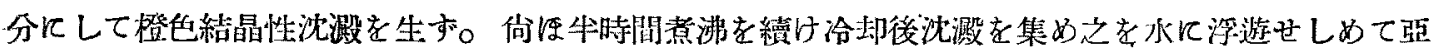

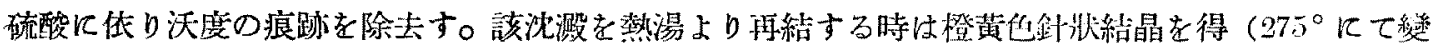
色し始め $300^{\circ}$ 亿て分解す)。

斯くして得たる Iodid を我に浮遊せしめ䉼に沈源せしめたる監化銀を以て約一時間處理し沃化銀

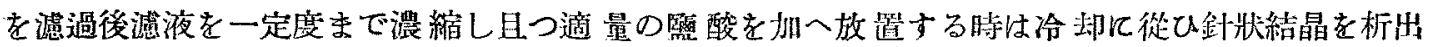
す。該結晶を㓐湯(含監酸)より再絬する時は Sinactiniumchloridの橙色企晶を析出し其の融點、諸 性質等 Perkin の記藏せる epiBerberiniumchlorid の其等と一致せ り。

不活性 Sinactin

次ざに上述の Sinactiniumchlorid $1 \mathrm{~g}$. 酔酸 10 c.c, $15 \%$ 硫酸 100 c.c 及び過剩の亞鉛末を以つて

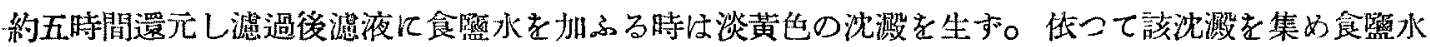

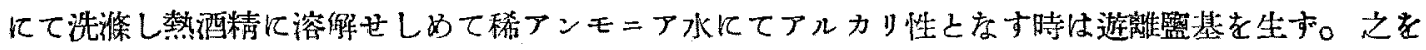
多量の熱酒精より再結し融點 $168^{\circ}$ の㶵色針晶を得たり。（理諭數 C 70.8，H 6.2；實驗數 C 71.0，

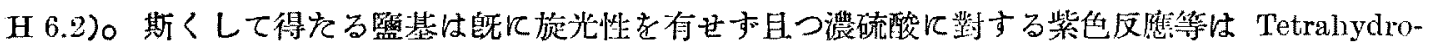
epiberberinのそれ等と一致するを見る。

此處飞於て Perkin 及び Hawrorth 等の合成せる Tetrahydroepiberberin（融點 166-167 ${ }^{\circ}$ ) 之余等の 得をる上記不活性 Sinactin（融點 $168^{\circ}$ ) とを混融せしめちるに $166^{\circ}$ にて融解し全く同一物なる事を 證明し得无り。

不活性 Sinactin の咀酸壁は多量の水上り細針昆となりて析出し分解點 $286^{\circ}$ なり且つ又 Perkin の記载により Methosulphate を作りをると融點 $275^{\circ}$ の㷛色大柱晶を得、台活その Iodid は $275^{\circ}$ にて融解し共に Perkin の記械と一致す。

終りに臨み R. D. Haworth 㸚授の合成 Tetrahydroepiberberin を御䢝附下されし御好意几梁く感 竧す。

(北里研究所几於て)

\section{古代支那貨幣の化學的研究（第一報）}

(昭和五年五月甘九日受䛔 昭和五年八月甘五日印刷)

道野鹤 松

\section{緒言}

古代の文明諸國に於いて、石器時代に次いで超歷史的の古い時代から金屬を用ひを時代のあつた てとは、と、K改めて中すまですありませんが、金屬の中でも最り古くから知られ且つ利朋されて

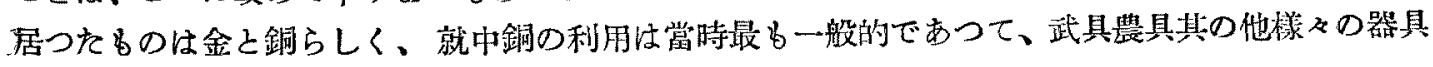
は之を以て作られてねをるのと推測されます。

古代の支那に於をむしては、一般に金なる文字を以て金犀全體を表はし、色に訨つて三種、或凹

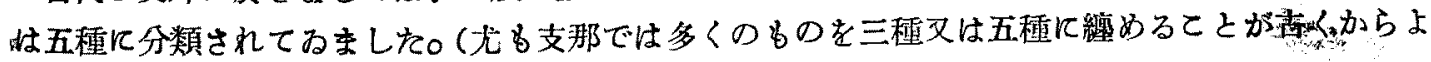

